\title{
RASIONALISASI LAPORAN BANTUAN SOSIAL BULAN MEI 2020 KEPADA MASYARAKAT TERDAMPAK COVID-19 PROVINSI KALIMANTAN TENGAH
}

\author{
Muhamad Reza Humaidi \\ Magister Ilmu Ekonomi, Universitas Palangka Raya \\ Jl. Turi No. 42, Kota Palangka Raya \\ mrezahumaidi@gmail.com
}

\begin{abstract}
Abstrak
Tujuan Penelitian ini adalah untuk mengetahui Rasionalitas Anggaran Laporan Bantuan Sosial Mei 2020 kepada Masyarakat yang Terkena Dampak COVID-19 Provinsi Kalimantan Tengah, Penelitian ini menggunakan Metode Deskriptif Kualitatif. Oleh karena itu Hasil Penelitian ini menyatakan, bahwa Laporan Bantuan Sosial kepada Masyarakat Yang Terkena Virus Corona 2019 (COVID-19) pada Bulan Mei 2020 Provinsi Kalimantan Tengah telah berjalan dengan baik dan laporan tersebut sangat rasional. Hal itu dikarenakan beberapa hal yang perlu menjadi fokus utama dalam upaya pemerintah menangani Anggaran COVID-19, antara lain; Tersedianya anggaran yang efektif untuk penanganan pandemi COVID-19 pada APBD 2020, Ketersediaan sarana dan prasarana kesehatan yang mampu menangani COVID-19, Kesiapan tenaga medis baik kualitas maupun kuantitas, Hindari Panik Membeli dan menyesuaikan sesuai kebutuhan, Tersedianya transparansi anggaran pemerintah dengan realisasi bantuan sosial, Ketersediaan bahan pangan, Bantuan sosial yang disalurkan kepada masyarakat harus tepat sasaran, Pengembangan potensi Pendapatan Asli Daerah, dan Optimalisasi bantuan sosial dan kesehatan dari pusat. dan pemerintah daerah.
\end{abstract}

Kata Kunci: Rasionalitas Anggaran, COVID-19, Provinsi Kalimantan Tengah

\begin{abstract}
The Purpose of this Research is to know about The Rationality Of The May 2020 Social Assistance Report Budget to Communities affected by COVID-19, Central Kalimantan Province. This research uses a descriptive qualitative method. Therefore, the results of this study, that the Social Assistance Report to Communities Affected by the Corona Virus 2019 (COVID-19) in May 2020, Central Kalimantan Province has been going well and the report is very rational. This is due to several things that need to be the main focus in the government's efforts to handle the COVID-19 Budget, these include; Availability of an effective budget for handling the COVID-19 pandemic in the 2020 APBD, Availability of health facilities and infrastructure that are capable of dealing with COVID-19, Readiness of medical personnel in terms of both quality and quantity, Avoid Panic Buying and adjust it as needed, Availability of government budget transparency with the realization of social assistance, The availability of foodstuffs, Social assistance distributed to the community must be right on target, Developing the potential for Regional Original Revenue, and Optimization of social and health assistance from central and local governments.
\end{abstract}

Keywords: Budget Rationality, COVID-19, Central Kalimantan Province.

\section{PENDAHULUAN}

Organisasi Kesehatan Dunia atau World Health Organization (WHO) menyatakan Corona Virus Disease 2019 (COVID-19) ialah sebuah pandemi yang terjadi pada sebagian besar negaranegara di seluruh dunia, termasuk di Indonesia, yang menunjukkan peningkatan dari waktu ke waktu dan telah menimbulkan korban jiwa, dan kerugian finansial yang semakin besar, sehingga berimbas pada berbagai aspek yaitu; aspek sosial, ekonomi, dan kesejahteraan masyarakat.

Pandemi Corona Virus Disease 2019 (COVID-19) di Indonesia berdampak terhadap perlambatan pertumbuhan ekonomi nasional, penurunan penerimaan dan pendapayan negara, serta peningkatan belanja negara dan pembiayaan, yang berakibat semunya terkena imbasnya. Sehingga diperlukan berbagai bentuk upaya Pemerintah untuk melakukan jaminan kesehatan masyarakatnya dan perekonomian nasional, dengan fokus pada belanja untuk kesehatan, jaring 
pengaman sosial (social safety net), serta pemulihan perekonomian yang didalamnya termasuk untuk dunia usaha dan masyarakat yang terdampak COVID-19. Atas pertimbangan di atas Pemerintah telah mengeluarkan Peraturan Pemerintah Pengganti Undang-Undang Nomor 1 Tahun 2020 tentang Kebijakan Keuangan Negara dan Stabilitas Sistem Keuangan untuk Penanganan Pandemi Corona Virus Disease 2019 (COVID-19) dan/atau Dalam Rangka Menghadapi Ancaman yang Membahayakan Perekonomian Nasional dan/atau Stabilitas Sistem Keuangan (Perppu 1/2020).

Kewenangan pemerintah yang terkait dengan pelaksanaan kebijakan keuangan negara berdasarkan Perppu 1/2020, diantaranya yaitu menetapkan batasan defisit anggaran, melakukan penyesuaian besaran belanja wajib (mandatory spending) sebagaimana diatur dalam ketentuan peraturan yang terkait, serta melakukan pergeseran anggaran antarunit, antarfungsi, dan antarprogram pada organisasi, melakukan (refocusing) anggaran dengan kegiatan yang berguna dan berkualitas bagi masyarakat, penyesuaian alokasi, dan pemotongan atau penundaan penyaluran anggaran Transfer ke Daerah dan Dana Desa, dengan kriteria tertentu, serta memberikan hibah kepada Pemerintah Daerah.

Sedangkan kewenangan yang diberikan kepada Pemerintah Daerah berkaitan dengan kebijakan di bidang keuangan negara sebagaimana diatur dalam Perppu 1/2020 diantaranya adalah Pemerintah Daerah diberikan kewenangan untuk melakukan pengutamaan penggunaan alokasi anggaran untuk kegiatan tertentu (refocusing), perubahan alokasi, dan penggunaan Anggaran Pendapatan dan Belanja Daerah dengan berpedoman kepada Peraturan Menteri Dalam Negeri.

Virus corona merupakan virus yang menginfeksi berbagai macam spesies termasuk manusia. Pandemi virus corona telah mengguncang dunia. Namun dengan tekad dan determinasi, virus ini bukannya tidak terkalahkan. Melansir data dari laman Worldometers, total kasus COVID-19 di dunia terkonfirmasi sebanyak 15.080 .860 (15 juta) kasus hingga Rabu (22/7/2020). Dari jumlah tersebut, sebanyak 9.102.398 (9,1 juta) pasien telah sembuh, dan 618.407 orang meninggal dunia. Kasus aktif hingga saat ini tercatat sebanyak 5.360.055 dengan rincian 5.296.258 pasien dengan kondisi ringan dan 63.797 dalam kondisi serius. Indonesia juga merasakan imbas penyebaran virus COVID-19. Total kumulatif positif virus corona di Indonesia mencapai 91.751 kasus. Dilansir dari situs resmi Kementerian Kesehatan, dari jumlah tersebut, 50.255 orang sembuh dan 4.459 orang lainnya meninggal dunia. Sedangkan pasien yang sedang dalam perawatan mencapai 37.037 orang.

Begitupula di Kalimantan Tengah, hingga 28 Juli 2020 diketahui Sebanyak 1664 Jiwa terinfeksi Virus Corona, dari jumlah tersebutnya sebanyak $90(5,41 \%)$ Jiwa meninggal dunia dan $1128(67,78 \%)$ Jiwa berhasil sembuh dan $446(26,81 \%)$ Jiwa masih dalam perawatan. (Media Center Gugus Tugas Covid-19, 2020) Dengan perkembangan kasus perhari seperti pada Gambar 1. Kondisi tersebut berdampak pada kondisi ekonomi di Indonesia tidak terkecuali Provinsi Kalimantan Tengah. Dampak yang terjadi di Indonesia juga terjadi pada provinsi Kalimantan Tengah yaitu, pelemahan mata uang rupiah, penurunan pertumbuhan ekonomi, kelesuan daya beli masyarakat, kelesuan produksi barang dan jasa, pelemahan IHSG, PHK Masal .

Dalam rangka pelaksanaan kebijakan di bidang keuangan daerah dalam rangka penanganan dan percepatan COVID-19, Pemerintah Daerah punya kewajiban untuk menangani penyebaran COVID-19 dan meminimalisir kerugian yang disebabkan oleh COVID-19 dengan memberikan bantuan sosial atau ekonomi kepada masyarakat yang terdampak COVID-19. Apakah anggaran bantuan sosial yang telah dianggarkan pemerintah sudah rasional dengan apa yang di perlukan sesuai dengan keperluan daerah. Apakah selama ini anggaran yang dibuat pemerintah sudah benar dan sesuai dan bagaimana realisasinya dengan bulan sebelumnya. Peneliti memilih bulan mei dikarenakan laporan terakhir yang dipublikasi oleh pihak pemerintah daerah yaitu bulan mei tahun 2020. Melihat permasalahan di atas, makalah ini dibuat untuk melihat Rasionalisasi Laporan Bantuan Sosial kepada Masyarakat yang Terdampak Corona Virus Disease 2019 (COVID-19) bulan Mei Tahun Anggaran 2020 Provinsi Kalimantan Tengah.. 


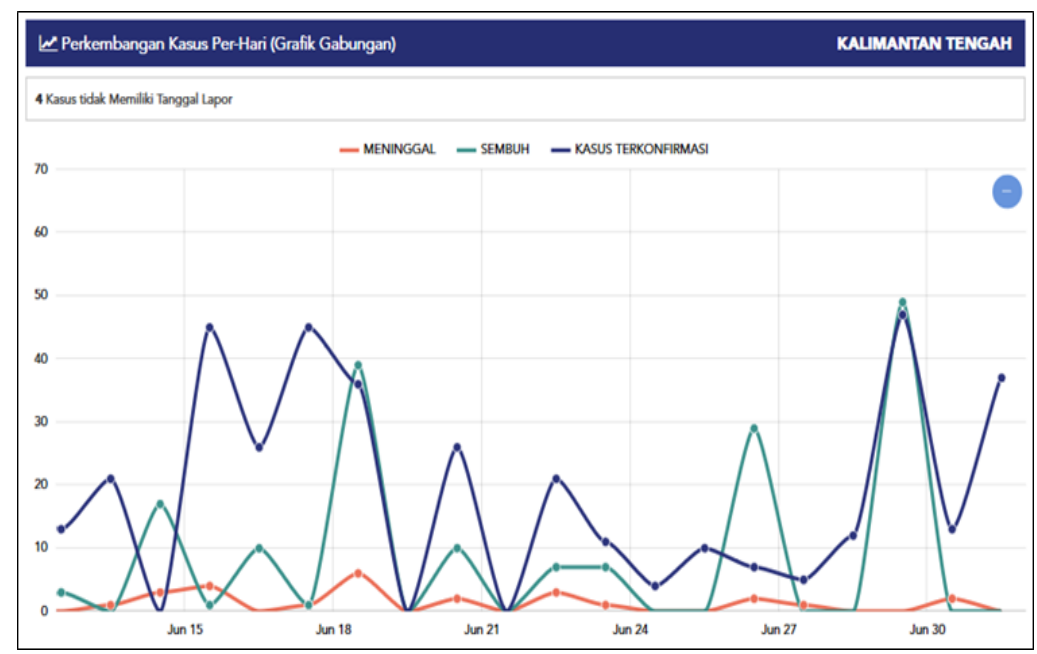

Gambar 1 Data Perkembangan Kasus COVID-19 perhari pada bulan Juni 2020

\section{TINJAUAN PUSTAKA}

\subsection{Kebijakan Pemerintah dan Kegiatan Ekonomi}

Pandangan-pandangan yang dikemukakan oleh para ekonom yang mengembangkan teori konjungtur riil berhubungan dengan ahli-ahli ekonomi Klasik. Dalam penentuan kegiatan ekonomi semuanya ditentukan oleh segi penawaran, yaitu ditentukan oleh faktorfaktor riil. Faktor moneter tidak berpengaruh terhadap penentuan tingkat pendapatan nasional riil. Sesuai dengan pandangan ini, para ekonom yang mengembangkan teori konjungtur riil tidak perlu mengamati kebijakan moneter dalam mempengaruhi tingkat kegiatan ekonomi, kesempatan kerja dan tingkat pendapatan nasional riil. Menurutnya perubahan penawaran uang tidak diikuti oleh perubahan faktor-faktor rill jadi hanya akan mempengaruhi tingkat harga.

Pandangan teori konjungtur riil lebih positif dalam menilai kebijakan fiskal yang berbeda dengan moneter. Menurut para ekonom, kebijakan-kebijakan fiskal yang dapat mempengaruhi faktor-faktor riil akan mewujudkan perubahan dalam setiap kegiatan ekonomi. Contohnya, pada pengurangan pajak terhadap individu maupun perusahaan akan dapat menambah penawaran tenaga kerja dan meningkatkan investasi yang diikuti oleh perkembangan teknologi. Perubahan seperti ini dapat menambah kesempatan kerja dan pendapatan nasional riil. Kebijakan fiskal yang menghindari terjadinya defisit dalam suatu anggaran belanja pemerintah merupakan langkah fiskal lain yang mempunyai efek yang positif terhadap kegiatan ekonomi.

\subsection{Kerja Teori Rasionalisasi}

Teori Rasionalisasi dicetuskan pertama kali oleh Max Weber, yang bersamaan dengan lahirnya kapitalisme modern. Kapitalisme modern yaitu hasil akhir dari proses rasionalisasi yang berakar dalam tradisi intelektual spesifik. Teori ini berdasar pada pemahaman "rasionalitas" khususnya "rasionalitas tindakan". Menurut Max Weber cara berpikir dan bertindak ini adalah "masalah inti dalam sejarah universal peradaban". (John Scoot, 2012) Rasionalitas adalah anggapan yang memungkinkan kita untuk membuat suatu pilihan berdasarkan standard logis, dan tidak akan secara sengaja membuat keputusan yang akan menjadikan mereka lebih buruk. Standard tersebut atau aksioma tersebut merupakan penyederhanaan dari sebuah komplekstisitas dan nilai-nilai.

Rasionalisasi adalah cara, proses, perbuatan menjadikan bersifat rasional; proses, cara, perbuatan merasionalkan. Rasionalisasi adalah proses, cara, perbuatan yang rasional (menurut rasio) atau menjadikan nisbahnya patut (baik). Rasionalisasi adalah perbaikan dalam perusahaan dengan menghemat tenaga kerja dan biaya serta mempertinggi produksi; perbaikan nisbah antara berbagai komponen dalam perusahaan sehingga perusahaan menjadi sehat (Kamus Besar Bahasa, 2016). 
Menurut John Dewey, Rasionalitas manusia sebagai berikut: (Shulamit Gribov, 2011)

1) Ide-ide yang diuraikan dalam pemikiran rasional berbentuk (data).

2) Memperkuat bukti tentang ide-ide ini dan menyimpulkan melalui kesaksian atau percobaan.

3) Timbul dari solusi yang berbentuk spekulatif, hipotesis, inferensi atau teori.

4) Timbul rasa ingin tahu sebagai bentuk adaptasi terhadap hal-hal yang sulit untuk mengetahui sifat, atau dalam menjelaskan hal-hal yang muncul tiba-tiba

5) Kemudian memberikan arti dari definisi yang bagi masalah yang sulit.

\section{Rasionalitas Ekonomi}

Rasionalitas Ekonomi dapat diartikan ketika melihat seorang atau kelompok pengambil keputusan dalam pembuatan kebijakan menimbang besarnya biaya yang di keluarkan dengan manfaat yang di dapatkan sebagai efisiensi dari penggunaan sumbar daya yang dimiliki. Semakin besar manfaat kebijakan, dan semakin sedikit biaya, semakin besar kemungkinan kebijakan akan dipilih. Pembuat kebijakan melakukan hal sebagai berikut:

1) Pembuat keputusan dihadapkan pada suatu masalah yang dapat diperbandingkan satu sama lain.

2) Tujuan-tujuan, ketentuan-ketentuan, atau sasaran yang mempedomani pembuat keputusan amat jelas dan dapat ditetapkan rangkingnya sesuai dengan urutan kepentingannya

3) Berbagai altenatif untuk memecahkan masalah tersebut diteliti secara saksama.

4) Akibat-akibat (biaya dan manfaat) yang ditmbulkan oleh setiap altenatif yang dipilih diteliti.

5) Setiap alternatif dan masing-masing akibat yang menyertainya, dapat diperbandingkan dengan alternatif-altenatif lainnya.

6) Pembuat keputusan akan memilih alternatif' dan akibat-akibatnya yang dapat memaksimasi tercapainya tujuan, nilai atau Sasaran yang telah digariskan.

\section{Jenis-Jenis Rasionalitas}

Berikut Ini Merupakan Jenis - Jenis Rasionalitas. Terbagi menjadi dua yaitu;

1) Self Interest Rationality (Rasionalitas Kepentingan Pribadi)

Prinsip pertama dalam ilmu ekonomi menurut Edgeworth, bahwa setiap pihak digerakkan oleh (self interest) seorang individu atau diri sendiri. Hal ini mungkin saja benar pada masa-masa Edgeworth, tapi salah satu pencapaian dari teori utilitas modern adalah pembebasan ilmu ekonomi dari prinsip pertama yang meragukan tersebut.

Pengertian kepentingan pribadi disini tidak selalu diartikan dengan penumpukan kekayaan dan harta oleh seseorang. Dimana kepentingan pribadi yang di asumsikan disini ialah setiap individu akan selalu berupaya mengejar berbagai tujuan dalam hidup ini, dan tidak hanya memperbanyak kekayan secara moneter.

2) Present Aim Rationality (Rasionalitas Berdasarkan Tujuan yang Ingin Dicapai Saat Ini) Teori kepuasan modern yang aksiomatis tidak berasumsi bahwa manusia selalu bersikap mementingkan dirinya sendiri. Teori ini berasumsi bahwa manusia selalu menyesuaikan preferensinya sepanjang waktu dengan sejumlah prinsip.

Secara jelasnya dikatakan bahwa preferensi yang diambil haruslah konsisten. Penyesuaian terhadap prinsip ini tanpa harus menjadi hanya mementingkan diri sendiri (Self Interest) sehingga setiap waktu mungkin preferensi individu tersebut dapat berubah sesuai dengan kebutuhan yang ingin dicapainya.

\subsection{Ruang Lingkup Pemerintah Daerah}

Definisi Pemerintahan Daerah di dalam UU No. 23 Tahun 2014 tentang pemerintahan daerah pasal 1 ayat 2, adalah sebagai berikut:

"Pemerintahan Daerah adalah penyelenggaraan urusan pemerintahan oleh pemerintahan daerah dan DPRD menurut asas otonomi dan tugas pembantuan dengan prinsip otonomi yang seluas-luasnya dalam sistem dan prinsip NegaraKesatuan Republik Indonesia sebagaimana dimaksud dalamUndang-Undang Dasar Negara Republik Indonesia Tahun 1945". 
Menurut Suhady dan Riawan, Pemerintah (government) ditinjau dari pengertiannya adalah the authoritative direction and administor affairs of men/women in a nation state, city, etc. Dalam bahasa Indonesia sebagai pengarahan dan administrasi yang berwenang atas kegiatan masyarakat dalam sebuah Negara, kota dan sebagainya. Pemerintahan dapat diartikan juga sebagai the governing body of a nation, state, city, etc yaitu lembaga atau badan yang menyelenggarakan pemerintahan Negara, Negara bagian, atau kota dan sebagainya. Pengertian pemerintah dilihat dari sifatnya yaitu pemerintah dalam arti luas meliputi seluruh kekuasaan yaitu kekuasaan legislatif, kekuasaan eksekutif, dan kekuasaan yudikatif. Sedangkan pemerintah dalam arti sempit hanya meliputi cabang kekuasaan eksekutif saja.

\subsection{Motivasi Kerja}

Motivasi adalah daya pendorong yang mengakibatkan seseorang atau keseluruhan bawahan mau dan rela mengerahkan kemampuan, keahlian, dan waktu untuk mengerjakan tugas yang menjadi tanggung jawabnya dalam rangka mencapai tujuan dan sasaran organisasi yang telah ditetapkan (Hafied, 2016).

Motivasi sering, diartikan dengan istilah dorongan, yang berarti tenaga yang menggerakkan jiwa dan jasmani untuk berbuat sehingga motif merupakan "driving force" seseorang, untuk bertingkah laku dalam mencapai tujuan yang telah ditetapkan. Setiap orang mempunyai motif diri yang berbeda antara orang yang satu dengan yang lainnya (Marnis, 2014).

Terry (Sedarmayanti, 2009) mendefisikan bahwa motivasi adalah keinginan yang terdapat pada seseorang atau individu yang merangsangnya untuk melakukan tindakan. Motivasi adalah suatu kekuatan yang dihasilkan dari keinginan seseorang untuk memuaskan kebutuhannya, misal; rasa lapar, haus, dan dahaga.

Motivasi adalah kekuatan kecendrungan seseorang atau individu melibatkan diri dalam kegiatan yang mengarah kepada pekerjaan tertentu. Pengertian motivasi menurut Terry adalah keinginan yang terdapat pada diri seseorang individu yang mendorongnya untuk melakukan perbuatan-perbuatan (perilaku) tertentu (Notoatmodjo, 2009).

Stooner mendefinisikan bahwa motivasi adalah sesuatu hal yang menyebabkan dan yang medukung tindakan atau perilaku seseorang (Notoatmodjo, 2009). Flippo (Notoatmodjo, 2009) merumuskan bahwa motivasi adalah suatu arahan pegawai dalam suatu organisasi agar mau bekerja sama dalam mencapai keinginan para pegawai dalam rangka pencapaian keberhasilan organisasi.

Siagian (Sedarmayanti, 2009) menjelaskan bahwa motivasi adalah keseluruhan proses pemberian motivasi bekerja kepada bawahan sedemikian rupa sehingga mereka mau bekerja dengan ikhlas demi tercapainya tujuan organisasi dengan efisien dan ekonomis.

Motivasi adalah setiap usaha yang didasarkan untuk mempengaruhi perilaku seseorang dalam meningkatkan tujuan organisasi semaksimal mungkin. Motivasi mengacu pada dorongan dan usaha untuk memuaskan kebutuhan atau suatu tujuan (Notoatmodjo, 2009).

Jadi motivasi adalah keseluruhan proses pemberian motivasi bekerja kepada bawahan sedemikian rupa sehingga mereka mau bekerja dengan ikhlas. Upaya mencapai tujuan organisasi diharapkan dapat berjalan efisien dan ekonomis.

\section{Fungsi Pemerintah Daerah}

Fungsi pemerintah daerah dapat diartikan sebagai perangkat daerah yang menjalankan, mengatur dan menyelenggarakan jalannya pemerintahan daerah. Fungsi pemerintah daerah menurut Undang-Undang No. 23 Tahun 2014 adalah:

a) Pemerintah daerah dapat mengatur dan mengurus sendiri urusan pemerintahan menurut asas otonomi dan tugas pembantuan.

b) Menjalankan otonomi seluas-luasnya, kecuali urusan pemerintahan yang menjadi urusan pemerintahan dengan tujuan meningkatkan kesejahteraan masyarakat, pelayanan umum dan daya saing daerah.

c) Pemerintah daerah dalam menyelenggarakan urusan pemerintahan memiliki hubungan pemerintahan pusat dengan pemerintahan daerah. Dimana hubungan tersebut meliputi 
wewenang, keuangan, pelayanan umum, pemanfaatan sumber daya alam, dan sumber daya lainnya.

\section{Urusan-urusan Pemerintah daerah}

Melalui sistem pemerintahan daerah, pemerintahan daerah diberi wewenang untuk mengatur dan mengurus urusan-urusan yang diserahkan kepadanya. Dalam Pasal 13 Undang-Undang Nomor 23 Tahun 2014 sebagaimana telah diamandemen dengan Undang-Undang Nomor 12 Tahun 2008 Tentang Pemerintahan Daerah, urusan wajib yang menjadi kewenangan pemerintahan daerah provinsi yang merupakan urusan dalam skala provinsi yang meliputi:

a) Perencanaan dan pengendalian pembangunan.

b) Perencanaan, pemanfaatan, dan pengawasan tata ruang.

c) Penyelenggaraan ketertiban umum dan ketentraman masyarakat.

d) Penyediaan sarana dan prasarana umum.

e) Penanganan bidang kesehatan.

f) Penyelenggaraan pendidikan dan alokasi sumber daya manusia potensial.

g) Penanggulangan masalah sosial lintas kabupaten/kota.

h) Pelayanan bidang ketenagakerjaan lintas kabupaten/kota.

i) Fasilitasi pengembangan koperasi, usaha kecil, dan menengah termasuk lintas kabupaten/kota.

j) Pengendalian lingkungan hidup.

k) Pelayanan pertanahan termasuk lintas kabupaten/kota.

1) Pelayanan kependudukan, dan catatan sipil.

m) Pelayanan administrasi umum pemerintahan.

n) Pelayanan administrasi penanaman modal termasuk lintas kabupaten/kota.

o) Penyelenggaraan pelayanan dasar lainnya yang belum dapat dilaksanakan oleh kabupaten/kota.

p) Pengurusan wajib lainnya yang diamanatkan oleh peraturan perundangundangan.Pemerintah daerah dalam menyelenggarakan urusan pemerintahan memiliki hubungan pemerintahan pusat dengan pemerintahan daerah. Dimana hubungan tersebut meliputi wewenang, Pemerintah daerah dalam menyelenggarakan urusan pemerintahan memiliki hubungan pemerintahan pusat dengan pemerintahan daerah. Dimana hubungan tersebut meliputi wewenang,

\subsection{Bantuan Sosial Kepada Masyarakat}

Menurut Kementerian Sosial (2011:15) bantuan sosial adalah bantuan yang bersifat sementara yang diberikan kepada masyarakat miskin dengan maksud agar mereka dapat meningkatkan taraf kehidupannya secara wajar. Program bantuan sosial merupakan salah satu komponen program jaminan sosial yang menjadi bentuk realisasi tanggung jawab pemerintah atau pemerintah daerah yang sangat peduli terhadap kondisi masyarakat yang miskin dan terlantar di tingkat bawah. Program ini merupakan implementasi Undang-Undang Dasar 1945 Pasal 34 ayat 1 (2010:79) yang menyatakan bahwa fakir miskin dan anak-anak terlantar dipelihara oleh negara. Selain itu pada Undang-Undang Dasar 1945 Pasal 34 ayat 2 (2010:79) menyebutkan bahwa negara mengembangkan sistem jaminan sosial bagi seluruh rakyat dan memberdayakan masyarakat yang lemah dan tidak mampu sesuai dengan martabat kemanusiaan.

Dengan perkembangan sosial ekonomi suatu negara, program bantuan sosial yang semula hanya berbentuk hibah saja berubah orientasinya menjadi program yang lebih memberikan manfaat berkelanjutan melalui bantuan pemberdayaan atau stimulan agar sasaran program bantuan bisa menjadi mandiri dan tidak bergantung pada bantuan sosial lainnya di lain hari, kecuali bagi sasaran program yang memang sudah tidak potensial sama sekali seperti lanjut usia yang jompo, miskin terlantar dan lain-lain. Salah satu program pemerintah dalam mengentaskan kemiskinan yaitu dengan pemberian bantuan sosial kepada kepala keluarga miskin dengan membentuk kelompok kerja yang bergabung ke dalam Kelompok Usaha Bersama (KUBE), diharapkan dengan model bantuan tersebut dapat terentaskan kemiskinan.

Kelompok Usaha Bersama (KUBE) merupakan salah satu media pemberdayaan yang diciptakan untuk membangun kemampuan warga masyarakat atau keluarga miskin dalam 
memecahkan masalah, memenuhi kebutuhan dan mengembangkan potensi guna meningkatkan kesejahteraan sosialnya (Kementrian Sosial, 2011:9).

Laporan Bantuan Sosial kepada Masyarakat yang Terdampak Corona Virus Disease 2019 (COVID-19) bulan Mei Tahun Anggaran 2020 Provinsi Kalimantan Tengah

Dapat diketahui bahwa pemerintah telah melakukan beberapa bantuan sosial kepada masyarakat khususnya masyakat provinsi Kalimantan Tengah, Adapun Rincian laporan Bantuan Sosial kepada Masyarakat yang Terdampak Corona Virus Disease 2019 (COVID-19) bulan Mei Tahun Anggaran 2020 Provinsi Kalimantan Tengah berfokus pada Penanganan Dampak Ekonomi dan Bantuan Jaring Pengaman Sosial (Social Safety Net), adapun Anggaran-anggaran yang menjadi prioritas pemerintah yaitu, Honorarium Personil Gugus Tugas, Cetak dan Penjilidan, Banner/Spanduk, Bahan Bakar, Penggandaan, Alat Tulis Kantor (ATK), Alat Kelistrikan, Dokumentasi, Makan dan Minum, Kebutuhan Logistik seperti disenfektan, serta peralatan kerja yang diperlukan. (Laporan Bantuan Sosial COVID-19 Mei tahun 2020 Provinsi Kalimantan Tengah)

Instruksi Presiden Republik Indonesia nomor 4 tahun 2020 tentang Refocussing Kegiatan, Realokasi Anggaran, serta Pengadaan Barang dan Jasa dalam Rangka Percepatan Penanganan Corona Virus Disease 2019 (COVID-19). Isi instruksi tersebut diantaranya sebagai berikut;

1) Mengutamakan penggunaan alokasi anggaran yang telah ada untuk kegiatan-kegiatan yang mempercepat penanganan Corona Virus Disease 2019 (COVID-19) (Refocussing kegiatan, dan realokasi anggaran) dengan mengacu kepada protokol penanganan Corona Virus Disease 2019 (COVID-19) di Kementerian/Lembaga/Pemerintah Daerah dan rencana operasional percepatan penanganan COVID-19 yang ditetapkan oleh Gugus Tugas Percepatan Penanganan COVID-19.

2) Mempercepat refocussing kegiatan dan realokasi anggaran melalui mekanisme revisi anggaran dan segera mengajukan usulan revisi anggaran kepada Menteri Keuangan sesuai dengan kewenangannya.

3) Menteri Dalam Negeri untuk mengambil langkah-langkah lebih lanjut dalam rangka percepatan penggunaan Anggaran Pendapatan dan Belanja Daerah (APBD) atau perubahan peraturan kepala Daerah tentang penjabaran APBD untuk percepatan penanganan COVID-19 kepada Gubernur/Bupati/Walikota.

Isi peraturan Permendagri 20 Tahun 2020 tentang Percepatan Penanganan COVID-19 di Daerah sebagai berikut;

1) Untuk mengantisipasi dan menangani dampak penularan COVID-19, Kepala Daerah membentuk Gugus Tugas Percepatan Penanganan COVID-19 Daerah berdasarkan pertimbangan dan rekomendasi Ketua Pelaksana Gugus Tugas Percepatan Penanganan COVID-19 sesuai Keputusan Presiden mengenai Gugus Tugas Percepatan Penanganan COVID-19.

2) Penanganan COVID-19 di daerah dilakukan dengan memperhatikan arahan Ketua Pelaksana Gugus Tugas Percepatan Penanganan COVID-19.

3) Pendanaan yang diperlukan untuk keperluan Gugus Tugas Percepatan Penanganan COVID19 Daerah yang dibebankan pada APBD

4) Dalam melakukan langkah antisipasi dan penanganan dampak penularan COVID-19 sebagaimana dimaksud, Pemerintah Daerah dapat melakukan pengeluaran yang belum tersedia anggarannya, yang selanjutnya diusulkan dalam rancangan perubahan APBD.

5) Pengeluaran sebagaimana dimaksud dilakukan dengan pembebanan langsung pada belanja tidak terduga.

6) Dalam hal belanja tidak terduga sebagaimana dimaksud tidak mencukupi, Pemerintah Daerah menggunakan dana dari hasil penjadwalan ulang capaian program dan kegiatan lainnya serta pengeluaran pembiayaan dalam tahun anggaran berjalan dan/ atau memanfaatkan uang kas yang tersedia.

7) Penjadwalan ulang capaian program dan sebagaimana dimaksud diformulasikan terlebih dahulu dalam perubahan dokumen pelaksanaan anggaran satuan kerja perangkat daerah dalam waktu paling lama 1 (satu) hari. 
Isi Instruksi Menteri Dalam Negeri Republik Indonesia Nomor 1 Tahun 2020 Tentang Pencegahan Penyebaran dan Percepatan Penanganan Corona Virus Disease 2019 di Lingkungan Pemerintah Daera diantaranya melakukan percepatan pengutamaan penggunaan alokasi anggaran kegiatan tertentu (refocusing) dan/ atau perubahan alokasi anggaran yang digunakan secara memadai un tuk meningkatkan kapasitas:

1) Penanganan kesehatan dan hal-hal lain terkait kesehatan;

2) Penanganan dampak ekonomi terutama menjaga agar dunia usaha daerah masing-masing tetap hidup;

3) Penyediaan jaring pengamanan sosial/ social safety net.

\section{METODE PENELITIAN}

\subsection{Jenis dan Pendekatan Penelitian}

Jenis penelitian ini merupakan penelitian kualitatif, penelitian kualitatif ini merupakan suatu proses penelitian dan pemahaman yang berdasarkan pada metodologi yang menyelidiki suatu fenomena sosial dan masalah manusia, peneliti menekankan sifat realitas atau kenyataan yang terbangun secara sosial, hubungan erat antara peneliti dan subjek yang diteliti (Juliansyah Noor, 2012). Penelitian kualitatif dengan pendekatan deskriptif dalam penelitian ini dimaksudkan agar peneliti dapat mengetahui dan menganalisa apa yang terjadi pada realita dengan lugas, dalam dan rinci serta berupaya mengungkapkan data tentang beberapa hal yang perlu menjadi fokus utama dalam upaya pemerintah mengatasi dampak yang terjadi di masyarakat dengan Anggaran Bantuan Sosial untuk masyarakat yang terdampak COVID-19 khususnya masyarakat menengah kebawah.

\subsection{Teknik Pengumpulan Data}

Teknik Observasi adalah teknik pengumpulan data yang dilakukan melalui suatu pengamatan, dengan disertai pencatatan-pencatatan terhadap keadaan atau perilaku objek sasaran yang ingin diteliti (Fathoni, 2011) Bungin mengemukakan beberapa bentuk observasi yang dapat digunakan dalam penelitian kualitatif, yaitu observasi partisipasi, observasi tidak terstruktur, observasi kelompok tidak terstruktur. Fungsi dari Observasi ini adalah memperoleh data terkait aktivitas yang dilakukan oleh Pemerintah Daerah Provinsi Kalimantan Tengah.

Teknik Wawancara adalah teknik pengumpulan data melalui proses tanya jawab lisan yang berlangsung satu arah, artinya pertanyaan tanya jawab lisan yang berlangsung satu arah, artinya pertanyaan datang dari pihak yang mewawancarai dan jawaban diberikan oleh yang diwawancara. Melalui Teknik wawancara, data yang diperoleh adalah sebagai berikut. Hasil penelitian ini diambil dari 2 orang narasumber yang terdiri dari 1 orang pihak Sekretariat Daerah Provinsi Kalimantan Tengah dan 1 orang dari pihak Biro Pemerintahan dan Ekonomi Daerah.

a. Bagaimana Rasionalisasi Laporan Bantuan Sosial bulan Mei 2020 kepada Masyarakat terdampak COVID-19 Provinsi Kalimantan Tengah.

b. Apa saja Fokus utama upaya Pemerintah Daerah menangani Anggaran COVID-19.

Teknik dokumentasi digunakan untuk mengumpulkam data yang berupa setiap bahan tertulis, gambar, dan catatan yang dapat memberikan informasi. Melalui teknik ini peneliti berupaya untuk mencari data dari hasil sumber tertulis, melalui dokumen atau apa saja yang memiliki relevansi sehingga dapat melengkapi data yang diperoleh di lapangan.I

\section{PEMBAHASAN}

\subsection{Prediksi Berakhirnya COVID-19 di Indonesia}

Berdasarkan data tren global COVID-19 di Indonesia akan berakhir pada Oktober 2020 hal tersebut juga akan terjadi di provinsi Kalimantan tengah,. Hal itu tidak akan terlaksana jika tidak ada kerjasama antara pihak pemerintah dan masyarakat. Saat ini beberapa daerah sedang menajalankan era new normal yang lebih efektif dibandingkan PSBB guna memulihkan perekonomian masyarakat maupun daerah yang terdampak. Adapun Data trend global penyebaran covid serta perkiraan berakhirnya tersebut sebagai berikut. 


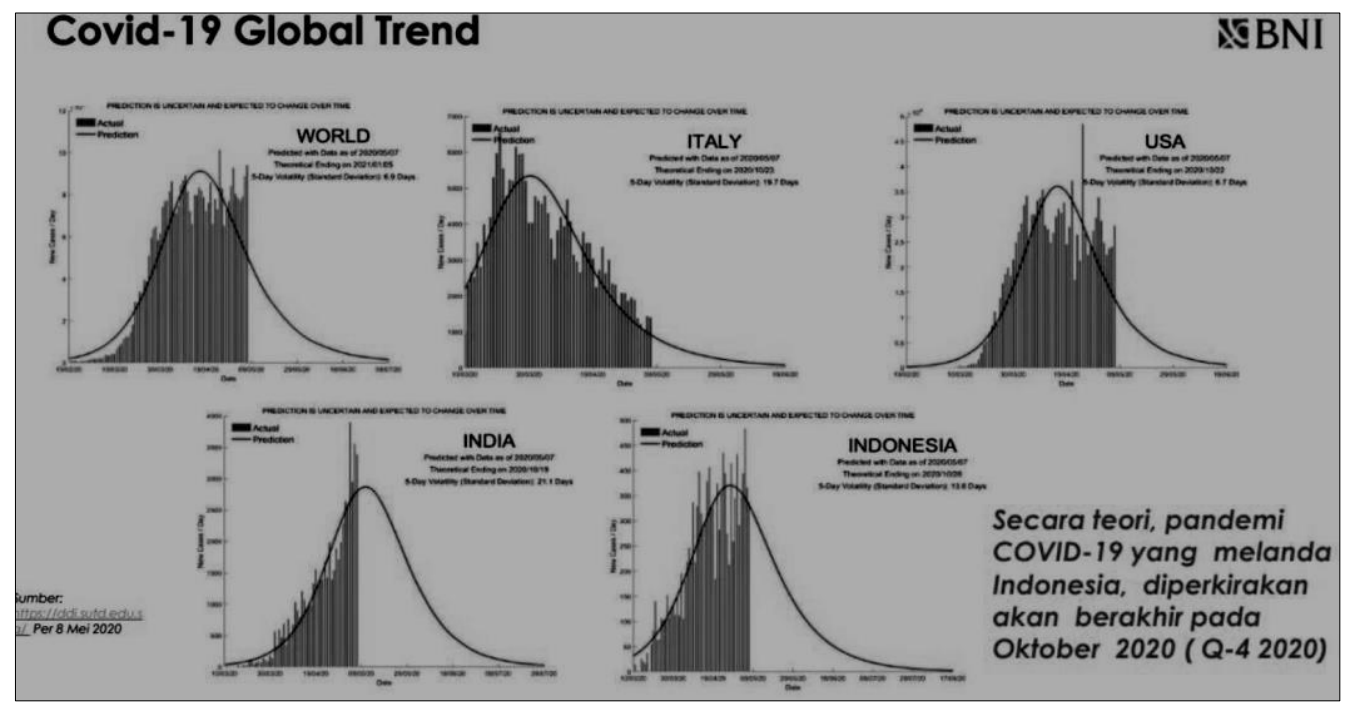

Gambar 2 Trend COVID-19 di Dunia dan beberapa Negara

(BNI, 8 Mei 2020)

\subsection{Perkembangan COVID-19 di Kalimantan Tengah}

Perkembangan kasus positif yang masih dirawat terus meningkat belum mengalami penurunan. Sampai saat ini kasus konfirmasi positif COVID-19 di Kalimantan tengah. Menurut satuan tugas COVID-19 Kalimantan Tengah diketahui pada 1 kota dan 13 kabupaten, tingkat sebaran konfirmasi tertinggi pertanggal 28 Juli 2020 ialah Kota Palangka Raya dengan kasus konfirmaasi sebanyak 613 orang, 198 pasien dalam perawatan, 371 pasien sembuh dan 44 dinyatakan meninggal dunia. Sedangkan tingkat sebarannya terendah yaitu kabupaten sukamara dengan hanya 2 yang terkonfirmasi COVID-19 dan dua-duanya sudah dinyatakan sembuh. Adapun data lengkapnya dibawah ini;



website resmi: https://corona.kalteng-go.id/

Gambar 3 Data Sebaran Pasien Covid - 19 Kalimantan Tengah Juli 2020

Angka penambahan harian masyarakat yang terkonfirmasi COVID-19 dikalimantan tengah, terus bertambah disetiap harinya dapat dilihat dari grafik perkembangannya sebagaiberikut; 


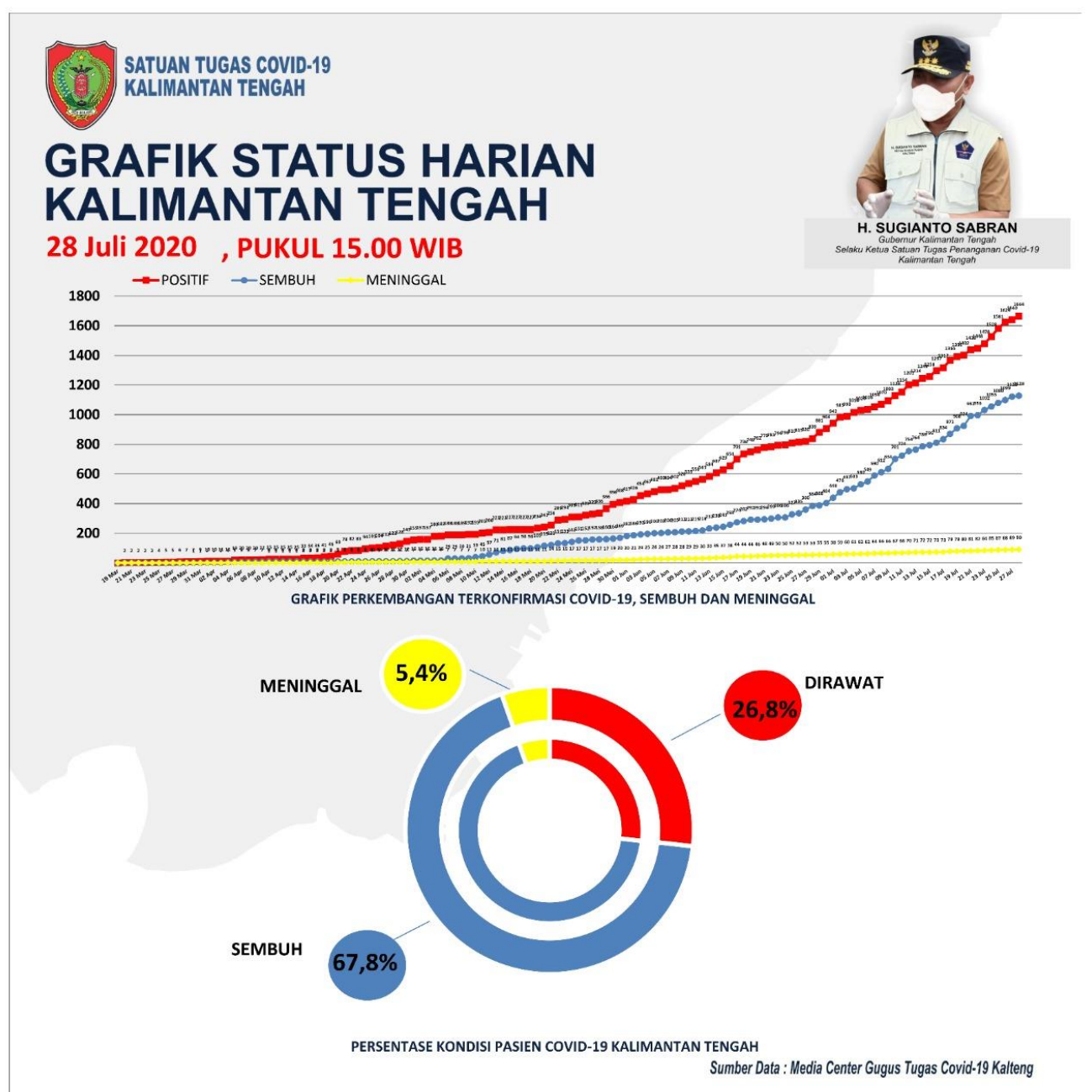

Gambar 4 Grafik Status Harian Covid - 19 Kalimantan Tengah Juli 2020

Dari data di atas diketahui hanya satu Kabupaten yaitu Sukamara yang sudah tidak terdapat pasien dalam perawatan. Sementara itu Kota Palangka Raya, Kotawaringin Barat, dan Barito Utara adalah Kabupaten/Kota yang angka penambahan jumlah konfirmasi kasus positif saat ini.

\subsection{Pemberian Bantuan Sosial dari Pemerintah Daerah kepada Masyakat}

Setelah Wabah COVID-19 dinyatakan sebagai bencana nasional dan pandemi, yang mana kemudian terhadap beberapa wilayah harus dilakukan pembatasan sosial berskala besar (PSBB). Hal ini menyebabkan dampak yang cukup signifikan terhadap kelangsungan kehidupan masyarakat, karena lapangan pekerjaan harian menjadi tidak bisa dilakukan, selain banyaknya gelombang PHK oleh perusahaan, karena ketidakmampuan perusahaan mempertahankan karyawan dalam situasi pandemi, maka akhirnya Pemerintah memberikan bantuan sosial (Bansos) sebagai bentuk tanggung jawab negara kepada masyarakat.

Pemerintah telah menerbitkan sejumlah kebijakan dalam menyikapi wabah virus corona (COVID-19) yang terjadi sejak awal Maret 2020, salah satunya dengan pembentukan Gugus Tugas melalui Keputusan Presiden Nomor 7 Tahun 2020 Tentang Gugus Tugas Percepatan Penanganan Corona Virus Disease 2019 (COVID-19) pada bulan Maret 2020, oleh karenanya gugus tugas ini sangat diharapkan melakukan penanganan yang optimal dalam masa bencana wabah COVID-19 ini, termasuk memberikan solusi perbaikan penyaluran Bansos COVID-19. 
Pemerintah merencanakan masih akan memberikan bansos kepada masyarakat terdampak selama wabah COVID-19 ini. Menteri Keuangan RI, dalam keterangannya kepada pers diberbagai pemberitaan menyatakan bahkan dimungkinkan selama tahun 2020, Pemerintah masih akan memberikan bansos kepada warga terdampak COVID19. Anggaran yang dialokasikan untuk penanganan wabah virus corona berkisar sekitar Rp. 677,2 triliun, yang dibagi dalam berbagai kebutuhan penanganan, seperti untuk penanganan Medis, APD dan lain sebagainya termasuk pemberian bantuan sosial (bansos).

Dikeluarkannya kebijakan pemerintah pusat untuk meminta daerah sebagai daerah siaga COVID-19, selain juga memberikanpenyuluhan kepada warga masyarakat tentang bahaya COVID-19, serta mempersiapkan dana talangan sosial untuk masyarakat. Banyaknya regulasi dan peraturan yang dikeluarkan oleh pemerintah yang tidak harmonis dan sejalan dengan masyarakat menimbulkan problematika baru di tengah masyarakat yang panik akibat wabah covid 19 ini. Masyarakat diwajibkan dan harus taat kepada kebijakan yang dikeluarkan oleh pemerintah, tetapi terdapat beberapa kebijakan yang dianggap tidak begitu penting bagi beberapa kalangan masyarakat, seperti pedagang yang kesulitan mencari nafkah dikarenakan PSBB. Sehingga dianggap PSBB tidak begitu efektif, maka dari itu pemerintah daerah menerapkan kebiasaan new normal sebagai pengganti PSBB sehingga membuat masyarakat tetap bisaa mencari nafkah di masa pandemi meskipun segala sektor perekonomian menurun diakibatkan pandemi COVID-19 ini.

Pemerintah daerah memberikan bantuan sosail kepada masyarakat yang terdampak COVID-19, termasuk Kalimantan Tengah, di Kalimantan tengah pemberian Bantuan telah disebarkan dan mandat pemberian bantuan diserahkan dari walikota dan bupati kepada lurah dan kepala desa agar bisa menyalurkan bantuan tersebut kepada masyarakat, selain itu di kota palangka raya bantuan social bisa diambil di kantor pos di masing-masing wilayah. bantuan sosial ini berupa uang.

\subsection{Masalah Penyaluran Bantuan}

Memahami kerumitan penyaluran bansos yang terjadi dan besarnya kesulitan Pemerintah dalam penyaluran bansos selama wabah COVID-19, maka perlu dilakukan evaluasi untuk penyelesaian akar permasalahan, yakni terkait pendataan warga penerima bansos. Antara lain tindakan yang perlu dilakukan pemerintah, adalah: 1) sinkronisasi data Pusat dan Daerah melalui E-KTP yang terdapat di catatan sipil, sehingga diketahui keseluruhan data warga dan jumlah penerima bantuan tahap 1 yang telah disalurkan, serta perbaikan data dari kejadian dan laporan yang terkonfimasi selama penyaluran tahap 1 dilakukan 2) Pemerintah Daerah dapat mendata manual melalui Kecamatan dan Desa/Lurah sebagai konfirmasi warga terdampak yang belum masuk dalam warga penerima bansos, sehingga warga terdampak yang sebelumnya tidak terdata dapat diberikan bansos; 3) meminta warga untuk melapor kepada Lurah/Desa untuk mendaftarkan sebagai penerima bansos akibat wabah COVID-19.

Tiga hal ini setidaknya dapat meminimalisir masalah penyaluran bansos tahap 2 (dua) yang selanjutnya masih akan dilakukan dalam masa wabah COVID-19, sehingga dengan perbaikan tersebut, masyarakat dapat merasakan bantuan yang tepat sasaran dan kedepannya diharapkan antara Pemerintah dan masyarakat dapat saling bersinergi untuk bertahan selama masa pandemi ini dan selanjutnya mencoba untuk meningkatkan perekonomian kembali.

\subsection{Jaringan Pengaman Sosial}

Program Jaringan Pengaman Sosial adalah suatu program yang dirancang untuk membantu rakyat miskin yang terkena dampak akibat krisis ekonomi dan dilaksanakan melalui tahapan penyelamatan dan pemulihan ekonomi menuju pada kondisi yang normal. Bantuan sosial untuk penanganan COVID-19 tidak berfokus pada satu program. Jaring Pengaman Sosial yang mencakup Program Keluarga Harapan (PKH), Kartu Prakerja, Kartu 
Sembako, Subsidi Listrik, dan Subsidi Insentif Perumahan Murah. Pemetaan ini diperlukan untuk mengidentifikasi alokasi anggaran untuk program JPS sudah menjaring sesuai sasaran.

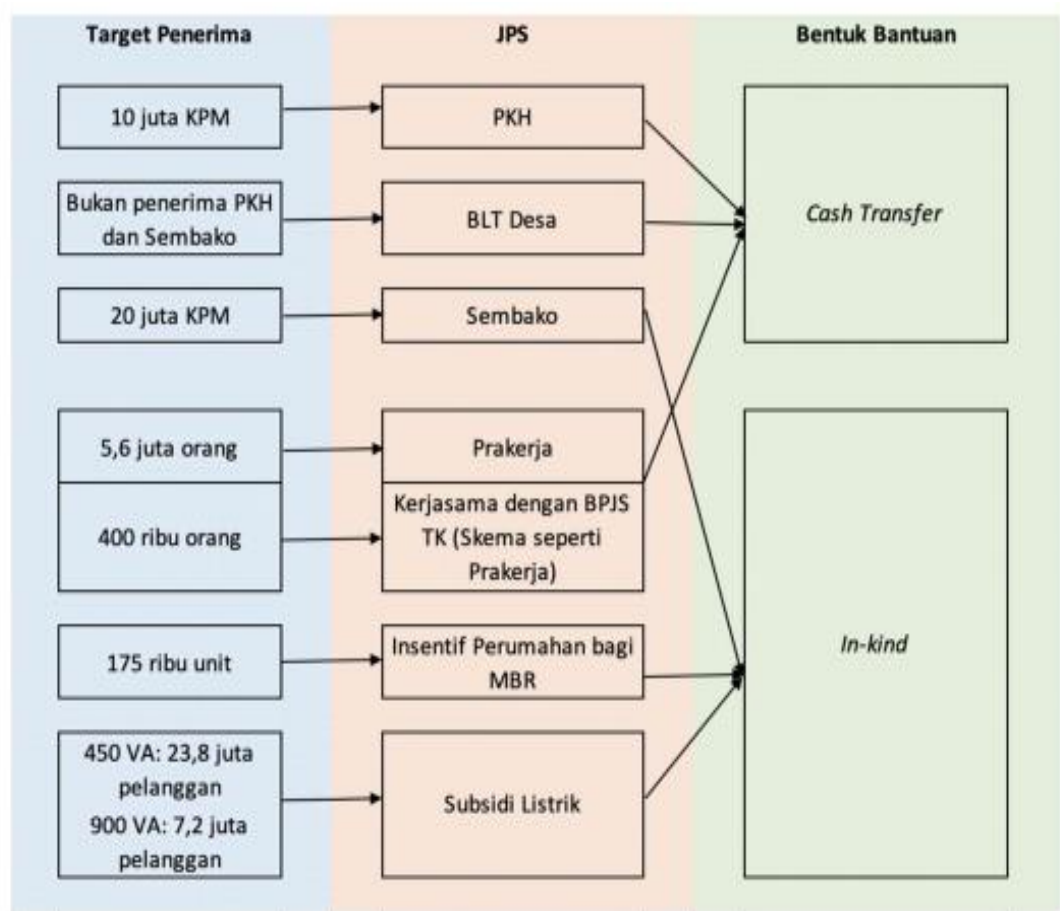

Gambar 5 Mapping Jaring Pengaman Sosial

\subsection{Penanganan COVID-19 dari Pemerintah Daerah}

Gubernur Kalimantan Tengah (Kalteng) keluarkan Surat Edaran tentang Kebijakan Terhadap Dampak Penanganan Pandemi COVID-19 di Kabupaten/ Kota se-Kalteng. Surat Edaran bernomor 443.1/27/2020/GT.COVID-19 ditujukan kepada Bupati/ Walikota se-Kalteng berdasarkan dengan ditetapkannya Status Tanggap Darurat Bencana Pandemi COVID-19 Prov.Kalteng melalui Keputusan Gubernur Kalteng Nomor 188.44/89/2020 tanggal 20 Maret 2020 tentang Status Tanggap Darurat Bencana Pandemi COVID-19 di wilayah Prov. Kalteng serta menindaklanjuti arahan Presiden RI dalam acara teleconference dengan Gubernur se-lndonesia pada tanggal 24 Maret 2020.

Dalam Surat Edaran tersebut, terdapat 8 Poin yang disampaikan Gubernur H. Sugianto Sabran diantaranya, Pertama ialah sampai saat ini COVID-19 telah menyebar di 196 Negara, hal ini menunjukan bahwa pandemi COVID-19 ini merupakan sebuah virus yang telah mendunia dan menjadi pandemi yang memang sangat sulit untuk dicegah.

Kedua, semua elemen satuan tugas penanganan COVID-19 harus satu visi dan memiliki kebijakan yang sama dan setiap kebijakan-kebijakan tersebut harus memperhitungkan aspek kesehatan dan keselamatan masyarakat maupun dampak sosial dan ekonomi yang mengikutinya.

Ketiga, setiap kebijakan yang diambil oleh Pemerintah Daerah harus dipersiapkan secara matang sehingga dapat menjadi langkah antisipatif terhadap akibat dari kebijakan tersebut, yakni mempersiapkan dukungan APBD berupa bantuan sosial bagi sektor-sektor dan pelaku ekonomi yang terdampak kebijakan pencegahan pandemi COVID-19. Lebih lanjut disampaikan, 3 hal yang menjadi fokus kebijakan diantaranya kesehatan dan keselamatan masyarakat, langkah antisipatif berupa bantuan sosialnya/ social safety net dan perhitungan terhadap dampak kebijakan sehingga dapat mempersiapkan langkahlangkah penanganannya.

Keempat, sehubungan dengan mitigasi dari dampak COVID-19 terhadap ekonomi masyarakat, Pemerintah Kabupaten/Kota agar memangkas rencana belanja yang tidak 
prioritas di APBD misalnya anggaran perjalanan dinas, pertemuan - pertemuan dan belanja - belanja lain yang tidak dirasakan langsung oleh masyarakat. Kemudian melakukan refocussing kegiatan dan melakukan realokasi anggaran untuk mempercepat penanganan COVID-19, dengan mengacu pada lnstruksi Presiden Nomor 4 Tahun 2020 tentang Refocussing Kegiatan, Realokasi Anggaran, serta Pengadaan Barang/ Jasa dalam rangka Percepatan Penanganan COVID-19. Refocussing kegiatan dan realokasi anggaran tersebut, bukan hanya untuk penanganan kesehatan untuk masyarakat, tetapi juga untuk penanganan dampak ekonomi masyarakat melalui bantuan-bantuan sosial.

Kelima, program kegiatan yang ada di kabupaten/ kota, diarahkan agar menjadi program padat karya tunai, tetapi dalam pelaksanaannya tetap harus mengikuti protokol kesehatan secara ketat untuk mencegah penularan COVID-19 dengan selalu menerapkan memakai masker, mencuci tangan dan menjaga jarak antara satu sama lain..

Keenam, masing-masing kabupaten/ Kota menghitung ketahanan Daerah masingmasing, baik ketahanan pangan, penurunan pendapatan, dan dampak ekonomi terutama bagi pelaku usaha mikro, kecil dan menengah. lni dilakukan sebagai dasar perumusan kebijakan yang komprehensif terhadap dampak penanganan COVID-19 di Daerah. Angka-angka ketahanan daerah tersebut di kalkulasi secara detil sehingga persiapanpersiapan bantuan sosial melalui refocussing kegiatan dan realokasi anggaran dapat segera dilakukan.

Ketujuh, selama masa tanggap darurat, diinstruksikan kepada Bupati/ Walikota beserta segenap pimpinan dan jajaran perangkat Daerah agar tidak melaksanakan perjalanan keluar daerah dan tetap ditempat masing-masing. Dalam hal mendesak agar menunjuk perwakilan saja.

Kedelapan, dalam pelaksanaannya agar Bupati/Walikota selalu berkoordinasi dengan Gubernur melalui Gugus Tugas Percepatan Penanganan COVID-19 Prov. Kalteng dan menyampaikan laporan secara berkala.

\subsection{Rasionalisasi Laporan Bantuan Sosial kepada Masyarakat yang Terdampak Corona Virus Disease 2019 (COVID-19) bulan Mei Tahun Anggaran 2020 Provinsi Kalimantan Tengah}

Dapat diketahui bahwa Laporan Bantuan Sosial kepada Masyarakat yang Terdampak Corona Virus Disease 2019 (COVID-19) bulan Mei Tahun Anggaran 2020 Provinsi Kalimantan Tengah pada bidang safety net, berfokus pada beberapa Instansi yaitu Badan Penanggulangan Bencana Pemadam Kebakaran, Biro Protokol dan Komunikasi Publik, Dinas Komunikasi, Informatika, Persandian dan Statistik, dan Dinas Sosial.

1) Badan Penanggulangan Bencana Pemadam Kebakaran, anggarannya terdiri dari;

a) Honorarium Personil Gugus Tugas

b) Cetak dan Penjilitan

c) Spanduk

d) Bahan Bakar Minyak

e) Meterai

f) Penggandaan

g) Dokumentasi

h) Alat Tulis Kantor (ATK)

i) Alat Listrik

j) Makan Minum

k) Logistik

1) Peralatan Kerja

m) Perjalanan Dinas dalam Rangka Pemantauan Lapangan

n) Distribusi/Pengiriman

o) Perbaikan dan Pergantian Sparepart

2) Biro Protokol dan Komunikasi Publik, anggarannya terdiri dari;

a) Bagian Protokol 
b) Bagian Publikasi Publik

3) Dinas Komunikasi, Informatika, Persandian dan Statistik, anggaran terdiri dari;

a) Iklan Layanan Masyarakat

b) Kegiatan Video Conference

c) Produksi Konten media massa

d) Liputan Khusus

e) Pembuatan Website Corona.kalteng.go.id

f) Kegiatan Siaran Keliling

g) SMS Broadcast dan sebagainya.

4) Dinas Sosial

a) Bantuan Sosial Bagi Keluarga Miskin atau Rentan Terdampak Covid

b) Honor tim pelaksana dan pengelola data

c) Alat Tulis Kantor

d) Fotocopy

e) Dokumentasi

f) Laporan Kegiatan Pemberian Bantuan

g) Materai 6000

h) Amplop

i) Biaya Rapat Pertemuan

j) Banner

k) Biaya Pengiriman Aalat Pelindung Diri dari Kementrian Sosial

1) Pendamping dan Pengawasan Penyaluran Bansos

Mengamati perkembangan dari situasi dan juga dampak dari penyebaran COVID-19 pada saat ini, yang mana hal tersebut berdampak pada realisasi anggaran belanja dan juga ikut mempengaruhi pendapatan daerah sehingga diperlukan pencermatan kembali terhadap APBD Provinsi Kalimantan Tengah tahun berjalan sekaligus sebagai tindak lanjut dari upaya Pemerintah Provinsi Kalimantan Tengah dalam menanggulangi penyebaran COVID-19 dengan menyediakan anggaran untuk kegiatan tersebut, maka pemerintah Provinsi Kalimantan Tengah mengambil langkah-langkah kebijakan anggaran sebagai berikut;

1) Mengurangi besaran Belanja Perjalan Dinas maksimal sebesar 50\% dari total Belanja Perjalana Dinas pada masing-masing SKPD.

2) Melakukan Perhitungan kembali terhadap kebutuhan barang operasional kantor seiring dengan berkurangnya aktivitas kantor, khususnya untuk Belanja ATK agar dilakukan rasionalisasi anggaran minimal 20\% dari pagu belanja habis pakai (ATK) yang tersedia pada DPA masingmasing SKPD.

3) Melakukan rasionalisasi sebesar 15\% DARI Belanja Honorium, Khususnya Honorium Panitia Pelaksana Kegiatan, Honorium PNS lainnya, Honorium Tenaga Ahli/Instruktur/Narasumber pada kegiatan yang mengalami penundaan atau tidak dapat dilaksanakan.

4) Melakukan Perhitungan kembali terhadap belanja makanan dan minuman kantor yang juga berkaitan dengan beberapa poin diatas, khususnya pada rekening belanja makanan dan minuman rapat agar dilakukan rasionalisasi anggaran minimal $20 \%$.

5) Melakukan pencermatan kembali terhadap kegiatan yang tertunda atau tidak dapat dilaksanakan sehubungan dengan penyebaran COVID-19, seperti kegiatan pameran, perayaan hari-hari besar, kegiatan sosialisasi/bimbingan teknis dll yang sifat nya menghadirkan banyak peserta dan juga khalayak yang ramai agar dibuat rekap kegiatan dan juga besaran anggarannya sesuai yang terlampir.

Maka dari itu dapat diketahui bahwa bahwa Laporan Bantuan Sosial kepada Masyarakat yang Terdampak Corona Virus Disease 2019 (COVID-19) bulan Mei Tahun Anggaran 2020 Provinsi Kalimantan Tengah sudah berjalan dengan baik dan laporan tersebut sangatlah rasional, akan tetapi lebih baik jika anggaran tersebut sejalan dengan realisasi anggaran tersebut, khususnya di bantuan social dikarenakan saat ini ekonomi masyarakat masih lesu dan diperlukan bantuan kepada masyarakat yang kesusahan dan terdampak COVID-19. 


\subsection{Penyaluran Bantuan COVID-19 di Kalimantan Tengah}

Gubernur Kalimantan Tengah (Kalteng) H Sugianto Sabran menegaskan bahwa penyaluran program bantuan sosial COVID-19 harus tepat sasaran, seperti masyarakat tidak mampu atau yang membutuhkan agar tetap memiliki daya beli terutama terhadap kebutuhan pokok. "Hindari penyimpangan bantuan sosial COVID-19. Jangan sampai masyarakat miskin yang berhak menerima tidak dibagi. Ini perlu kehati-hatian, supaya semua warga yang berhak menerima semua wajib kita bantu," Menurut Gubernur Sugianto Sabran.

H. Sugianto Sabran juga memerintahkan kepada seluruh jajarannya, khususnya Dinas Sosial, untuk tetap melakukan verifikasi dan validasi data penerima bantuan sosial tahap pertama yang telah tersalurkan, agar semua masyarakat tidak mampu yang benar-benar memerlukan dapat menerima bantuan sosial. "Setelah pembagian bantuan sosial tunai Pemerintah Provinsi Kalimantan Tengah sudah berjalan. Tapi kami tetap validasi, betul tidak yang menerima itu yang berhak menerima," jelasnya.

Senada Gubernur Kalteng H Sugianto Sabran, Koordinator Wilayah II Deputi Komisi Pemberantasan Korupsi (KPK) RI Asep Rahmat Suwandha pun mengungkapkan bahwa data penerima bantuan sosial memang harus terus diperbaiki. "Dalam fungsi koordinasi dan supervisi, kami mendorong Pemerintah Daerah, khususnya Kabupaten dan Kota segera membereskan kesimpangsiuran data, dengan belajar dari penyaluran tahap pertama. Karena data ini tidak hanya berguna saat COVID-19 ini saja, tapi juga ke depan.

\begin{tabular}{|c|l|c|c|c|}
\hline \multirow{2}{*}{ NO } & \multirow{2}{*}{ PROVINSI/KAB/KOTA } & \multicolumn{3}{|c|}{ SOSIAL SAFETY NET } \\
\cline { 3 - 5 } & & ANGGARAN & $\begin{array}{c}\text { REALISASI S.D. } \\
\text { JUNI 2020 }\end{array}$ & \multirow{2}{*}{$(\%)$} \\
\hline 1 & Provinsi Kalimantan Tengah & $191.159 .924 .304,00$ & $72.534 .420 .000,00$ & $37,94 \%$ \\
\hline 2 & Kota Palangka Raya & $15.000 .000 .000,00$ & $5.550 .000 .000,00$ & $37,00 \%$ \\
\hline 3 & Kabupaten Katingan & $27.700 .972 .618,00$ & - & $0,00 \%$ \\
\hline \multirow{2}{*}{4} & $\begin{array}{l}\text { Kabupaten Kotawaringin } \\
\text { Timur }\end{array}$ & $14.300 .000 .000,00$ & $3.308 .581 .250,00$ & $23,14 \%$ \\
\hline 5 & Kabupaten Kotawaringin Barat & $3.480 .503 .000,00$ & $3.262 .222 .000,00$ & $93,73 \%$ \\
\hline 6 & Kabupaten Lamandau & $43.236 .842 .428,00$ & $1.189 .544 .900,00$ & $2,75 \%$ \\
\hline 7 & Kabupaten Sukamara & $209.560 .600,00$ & $209.390 .600,00$ & $99,92 \%$ \\
\hline 8 & Kabupaten Seruyan & $14.220 .000 .000,00$ & - & $0,00 \%$ \\
\hline 9 & Kabupaten Pulang Pisau & 11.643 .623 .685 .05 & $161.500 .000,00$ & $1,39 \%$ \\
\hline 10 & Kabupaten Kapuas & $46.500 .000 .000,00$ & - & $0,00 \%$ \\
\hline 11 & Kabupaten Gunung Mas & 26.024 .639 .625 .00 & - & $0,00 \%$ \\
\hline 12 & Kabupaten Barito Selatan & $3.259 .798 .000,00$ & $190.596 .000,00$ & $5,85 \%$ \\
\hline 13 & Kabupaten Barito Timur & $52.800 .808 .905,20$ & - & $0,00 \%$ \\
\hline 14 & Kabupaten Barito Utara & - & - & $0,00 \%$ \\
\hline 15 & Kabupaten Murung Raya & $2.200 .000 .000,00$ & $1.736 .600 .000,00$ & $78,94 \%$ \\
\hline \multicolumn{2}{r|}{ Jumlah Keseluruhan } & $\mathbf{4 5 1 . 7 3 6 . 6 7 3 . 2 2 8 , 2 5}$ & $\mathbf{8 8 . 1 4 2 . 8 5 4 . 7 5 0 , 0 0}$ & $\mathbf{1 9 , 5 1 \%}$ \\
\hline
\end{tabular}

Tabel 1 Anggaran dan Realisasi Penanganan COVID-19 (Social safety Net) Januari s.d Juni 2020 Kalimantan Provinsi Kalimantan Tengah

Pertama, berdasarkan data tersebut Anggaran untuk Bantuan sosial safety Net/Jaring Pengaman Sosial tertinggi adalah untuk Provinsi Kalimantan Tengah sebanyak Rp.191.159.924.304. Selain itu, untuk Kota Palangka Raya Anggaran sebanyak Rp.15.000.000.000 dengan realisasi 37\% atau Rp. 5.550.000.000. Lalu untuk kabupaten yang memiliki Anggaran tertinggi ialah Kabupaten Barito Timur dengan nilai Rp. 52.800.808.905 Sedangkan jika dilihat dari angka realisasi tertinggi yaitu kabupaten sukamara dengan tingkat persentase realisasi sebanyak 99,92\%.

Kedua, berdasarkan data tersebut Anggaran untuk Bantuan sosial safety Net/ Jaring Pengaman Sosial terendah adalah kabupaten Barito Utara yang tidak memiliki anggaran untuk bidang ini. 
Sedangkan jika dilihat dari angka realisasi terendah yaitu Kabupaten Barito Timur dan kabupaten Gunung Mas dengan tingkat persentase realisasi yang sama yaitu 0\%. selain itu juga terdapat temuan bahwa untuk data realisasi anggaran ada beberapa daerah yang masih belum menerbitkan data realisasinya.

\section{KESIMPULAN}

Berdasarkan hasil penelitian, dapat diketahui bahwa bahwa Laporan Bantuan Sosial kepada Masyarakat yang Terdampak Corona Virus Disease 2019 (COVID-19) bulan Mei Tahun Anggaran 2020 Provinsi Kalimantan Tengah sudah berjalan dengan baik dan laporan tersebut sangatlah rasional, pemerintah sudah dirasa rasional memilih keputusan anggaran bantuan sosial bagi masyarakat, akan tetapi lebih baik jika anggaran tersebut sejalan dengan realisasi anggaran tersebut, khususnya di bantuan sosial dikarenakan saat ini ekonomi masyarakat masih lesu dan diperlukan bantuan kepada masyarakat yang kesusahan dan terdampak COVID-19. Dengan demikian semakin lama penanganan COVID-19 ini maka semakin besar dampak ekonomi yang terjadi serta semakin besar pula anggaran yang diperlukan dalam penanganan COVID-19. Maka dari itu ada beberapa hal yang perlu menjadi fokus utama upaya pemerintah menangani Anggaran COVID-19, hal tersebut diantara lain ialah; tersediannya anggaran yang efektif untuk penanganan Pandemi COVID-19 dalam APBD 2020; tersediannya sarana dan prasarana kesehatan yang mumpuni dalam menghadapi COVID-19; kesiapan tenaga medis baik dari segi kualitas maupun kuantitas; menghidari Panic Buying dan sesuaikan dengan kebutuhan; tersedianya transparansi anggaran pemerintah dengan realisasi bantuan social; ketersediaan bahan pangan alat pelindung diri, dan sebagainya; bantuan sosial yang disalurkan kepada masyarakat harus tepat sasaran; mengembangkan potensi Pendapatan Asli Daerah; dan pengoptimalan bantuan sosial maupun kesehatan dari pemerintah pusat maupun setempat.

\section{SARAN}

Berdasarkan hasil penelitian dan kesimpulan peneliti menyarankan segera melakukan New Normal dengan protokol kesehatan yang benar-benar diterapkan masyarakat. Sehingga aktivitas ekonomi bisa perlahan pulih dengan tetap menjaga kesehatan, sehingga pengeluaran pemerintah akan berkurang serta pendapatan pemerintah khususnya PAD akan sedikit demi sedikit akan meningkat.

\section{DAFTAR PUSTAKA}

Andhika, Pratama Tirta Wijaya. (2017). Pengaruh Efektivitas Lingkungan Pengendalian terhadap Pendeteksian Indikasi Fraud pada Laporan Keuangan Pemerintah Daerah (Studi Kasus pada Pemerintah Kabupaten Karanganyar). Universitas Andalas.

Artha Dharmakarja, I Gede Made. (2017) Rekonstruksi Belanja Bantuan Sosial Jurnal Substansi Volume 1 Nomor 2, 2017. Politeknik Keuangan Negara STAN.

Buletin Teknis Nomor 10 Komite Standar Akuntansi Pemerintahan tentang Akuntansi Belanja Bantuan Sosial. (2020) Dokumen Pemerintah Daerah Provinsi Kalimantan Tengah.

Bungin, B. (2003). Analisis Data Penelitian Kualitatif. Jakarta: PT. Raja Grafindo Persada.

Departemen Pendidikan Nasional. (2007). Kamus Besar Bahasa Indonesia (Balai Pustaka, Ed.). Jakarta.

Dian Fathma Alfina, Amrizal. (2020). Pengaruh Faktor Tekanan, Peluang, Rasionalisasi, Kompetensi, dan Arogansi Terhadap Kecurangan Laporan Keuangan. Akuntabilitas: Jurnal Ilmu Akuntansi Volume 13 (1), 2020, P-ISSN: 1979-858X; E-ISSN: 2461-1190 Page 63 76. Institut Teknologi dan Bisnis Ahmad Dahlan.

Gribov, Shulamit. (2001). John Dewey's Pragmatism and Moral Education, Simon Fraser University: Philosophyofeducation.

I Made Sinar Dewata Putra, I Kadek Ari Mahardika, dkk. (2017). Analisis Rasionalisasi Anggaran dan Dampak Adanya Rasionalisasi Anggaran Terhadap Pelaksanaan Program Kerja Pemerintah Daerah Kabupaten Buleleng. Jurnal Ilmiah Akuntansi dan Humanika, Vol. 7 No. 1, April 2017 ISSN: 2599-2651 . Universitas Pendidikan Ganesha, Bali.

Kementrian Sosial. (2011). Program bantuan sosial masyarakat miskin. 
Pemerintah Provinsi Kalimantan Tengah. (2020). Laporan Bantuan Sosial COVID-19 Mei tahun 2020 Provinsi Kalimantan Tengah.

Media Center Gugus Tugas Covid-19. (2020). Perkembangan COVID-19 di Kalimantan tengah.

Merissa Yesiariani, Isti Rahayu. (2017). Deteksi financial statement fraud: Pengujian dengan fraud diamond. Jurnal Akuntansi \& Auditing Indonesia. Program Studi Akuntansi, Universitas Islam Indonesia, Yogyakarta, Indonesia.

Muh Latif, Andy Fefta Wijaya, dan Tjahjanulin Domai. (2014) Perencanaan Anggaran Belanja Bantuan Sosial Pada Anggaran Pendapatan dan Belanja Daerah. Wacana Vol. 17, No. 2 (2014), ISSN : 1411-0199 E-ISSN : 2338-1884. Program Magister Ilmu Administrasi Publik, Fakultas Ilmu Administrasi, Universitas Brawijaya.

Noor, Juliansyah. (2012). Metodologi Penelitian. Jakarta: Kencana Prenada Media Group.

Novita Tresiana. Rasionalitas dan Pembuatan Keputusan Kebijakan. Jakarta : Graha Ilmu.

Peraturan Menteri Keuangan RI Nomor 168/PMK.05/2015 Tentang Mekanisme Pelaksanaan Anggaran Bantuan Pemerintah Pada Kementerian Negara/Lembaga

Permendagri 20 Tahun 2020 tentang Percepatan Penanganan COVID-19 di Daerah.

BNI. (2020). Trend Covid-19 di Dunia dan beberapa Negara. https://ddi.sutd.edu.sa.com.

Perppu 1/2020 Tentang Kebijakan Keuangan Negara dan Stabilitas Sistem Keuangan untuk Penanganan Pandemi Corona Virus Disease 2019 (COVID-19)

Qadratillah dan M. Takdir. (2011). Kamus Besar Bahasa Indonesia. Jakarta: Badan Pengembangan dan Pembinaan Bahasa, Kementrian Pendidikan dan Kebudayaan

Scott, John. (2012). Teori Sosial Max Weber. Yogyakarta. Pustaka Pelajar.

Undang-Undang Republik Indonesia Nomor 1 Tahun 2004 tentang Perbendaharaan Negara.

Undang-Undang Dasar 1945 Pasal 34 ayat 1 (2010) tentang fakir miskin dan anak-anak terlantar dipelihara oleh negara.

Undang-Undang Dasar 1945 Pasal 34 ayat 2 (2010) tentang negara mengembangkan sistem jaminan sosial bagi seluruh rakyat dan memberdayakan masyarakat yang lemah dan tidak mampu sesuai dengan martabat kemanusiaan.

Worldometers, total kasus COVID-19 di dunia terkonfirmasi sebanyak 15.080.860 (15 juta) kasus hingga Rabu (22/7/2020), https://www.worldometers.info/coronavirus/country/indonesia/.

\section{Biodata Penulis}

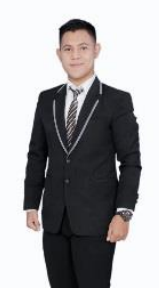

Muhamad Reza Humaidi, lahir pada tanggal 14 Juni 1997 di Kota Palangka Raya, Provinsi Kalimantan Tengah. Saat ini merupakan Mahasiswa Pasca Sarjana Universitas Palangka Raya. Menamatkan Pendidikan Sarjana Pada Fakultas Ekonomi dan Bisnis Islam, Institut Agama Islam Negeri (IAIN) Palangka Raya di tahun 2019. 